Received for publication: 23 September 2020 Accepted for publication: 20 January 2021 ISSN: $2616-4477$

(C) The authors. Published by Universidad Nacional Agraria La Molina DOI: http://dx.doi.org/10.21704/pja.v5i1.1680

\title{
Favorable morphoclimatic factors for the preservation of wetting organic carbon in mountain soils
}

\section{Factores morfoclimáticos favorables para la preservación del carbono orgánico humificado en suelos de montaña}

\author{
*Corresponding author: ssardonnina@gmail.com \\ *https://orcid.org/0000-0002-1999-1655
}

Sandro Sardón Nina ${ }^{1 *}$; Raúl D. Zapata Hernández ${ }^{2}$; Luis A. Arias López ${ }^{2}$

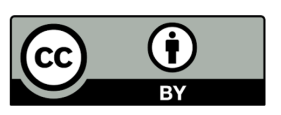

\begin{abstract}
Humic substances (HS) are the main component of soil organic matter (SOM), a product of the pedogenetic process. In this study, the morphometric factors and climatic variable that condition the degree of humification, the organic carbon content of humic acids (HA) fulvic acids (FA) of 42 soil samples are related through the functional equation of factors of state of the soil proposed by Jenny. The degree of humification was determined by the Nagoya method proposed by Kumada. The quantification of organic carbon was determined using the method by Walkley and Black. The morphometric parameters of the relief were obtained from the Digital Elevation Model (DEM) and the climate parameter of the MODIS sensor. The results show that the relief factor conditions the degree of humification and the climate factor conditions the organic carbon content of humic acids (HA) and fulvic acids (FA).
\end{abstract}

Keywords: Humic acids, fulvic acids, humification, morphometry, humic substances.

\section{Resumen}

Las sustancias húmicas (SH) son el componente principal de la materia orgánica del suelo (MOS), producto del proceso pedogenético. En este estudio, se relacionan los factores morfométricos y la variable climática que condicionan el grado de humificación, el contenido de carbono orgánico de los ácidos húmicos (AH) y ácidos fúlvicos (AF) de 42 muestras de suelos mediante la ecuación funcional de factores de estado del suelo propuesto por Jenny. El grado de humificación se determinó por el método Nagoya propuesto por Kumada. La cuantificación del carbono orgánico se determinó mediante el método de Walkley y Black. Los parámetros morfométricos del relieve se obtuvieron a partir del Modelo Digital de Elevación (MDE) y el parámetro climático del sensor MODIS. Los resultados muestran que el factor relieve condiciona al grado de humificación y el factor clima condiciona al contenido de carbono orgánico de los ácidos húmicos (AH) y ácidos fúlvicos $(\mathrm{AF})$.

Palabras clave: Ácidos húmicos, ácidos fúlvicos, humificación, morfometría, sustancias húmicas.

How to cite this article:

Sardón, S., Zapata, R., \& Arias, L. (2021). Favorable morphoclimatic factors for the preservation of wetting organic carbon in mountain soils. Peruvian Journal of Agronomy, 5(1), 35-43. http://dx.doi.org/10.21704/pja.v5i1.1680

\footnotetext{
${ }^{1}$ Universidad Nacional del Altiplano, Puno, Perú

${ }^{2}$ Universidad Nacional de Colombia, Medellin, Colombia
} 


\section{Introduction}

Soil organic matter (SOM) is the most complex and least-understood component of Soil Science. SOM is a mixture of residues of plants, microbes, and animals at various stages of decomposition and heterogeneous organic substances closely associated with the mineral fraction (Kononova, 1975; Christensen, 1992; Zaccone et al., 2018; Osorio, 2018; Gallardo, 2016).

SOM is composed of humic substances, which are a series of substances with a relatively high molecular weight that varies from a few hundred for fulvic acids to more than 300,000 for humic acids, presenting a color range from yellow to black, formed by secondary synthesis reactions (Stevenson, 1994).

According to Kumada (1987), humification is a set of processes that transform organic matter into compounds that have high visible light absorption capacity and high contents of organic groups such as carbonyl and carboxyl. Kumada (1987) was able to obtain information from HA molecules, such as: functional groups, elemental composition and degree of humification. For the degree of humification, it proposes to distinguish four types of humic acids A, $\mathrm{B}, \mathrm{Rp}$ and $\mathrm{P}$. This can be known through the formation of humic acids, in which the start of the humification process begins with the Rp type (first humification states of organic matter), evolving into type $\mathrm{B}$ and finally type A (each type exhibits a relatively stable form). In strongly acidic soils, the Rp type can be replaced by P-type soils.

Soil and SOM is the product of "soil formation state factors" and are expressed by the following functional equation (Jenny, 1941, 1980):

$$
\text { Soil and } \mathrm{SOM}=f(\mathrm{cl}, \mathrm{o}, \mathrm{r}, \mathrm{p}, \mathrm{t} \ldots)
$$

These state factors correspond to climate (cl), organisms (o), topography, or relief (r), parental material ( $\mathrm{p}$ ), and time ( $\mathrm{t})$. The ellipsis in the equation indicates that, in addition to the five factors mentioned above, other variables can be included. These soil-forming factors are independent variables that define the soil system. In this interpretation, the soil properties and the humification process become dependent variables and can be expressed based on soil-forming state factors.

Scientists in the soil area have different interpretations of the importance of forming factors concerning organic carbon content and degree of humification.

This research was developed to obtain quantitative relationships that condition the content of organic carbon in humic acids (HA), in fulvic acids (FA) and degree of humification with climate- and reliefindependent variables.

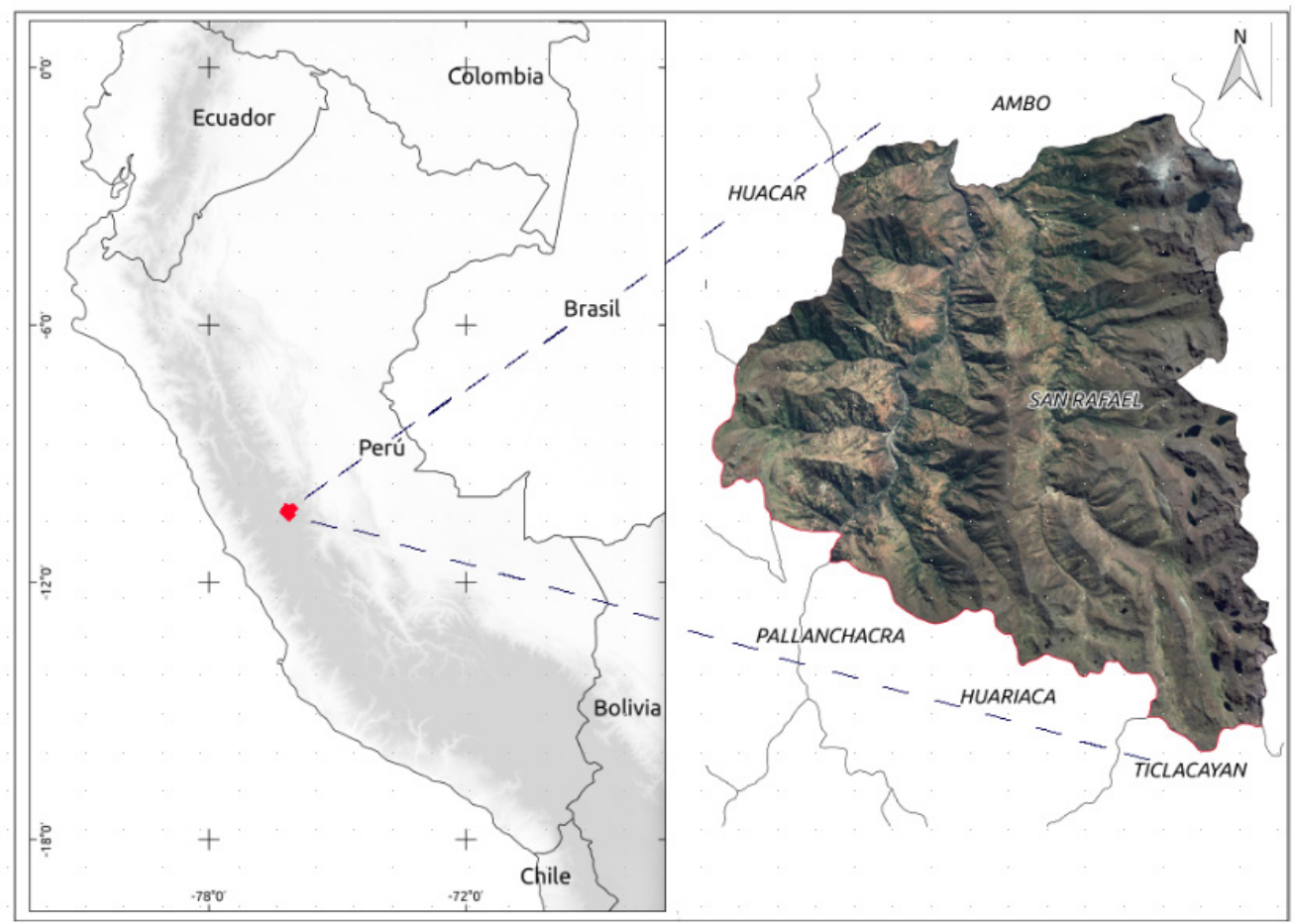

Figure 1: Location of the research area. 
Table 1: Location of the sampled points

\begin{tabular}{|c|c|c|c|}
\hline Soil sample & Land order (Soil Survey Staff) & South latitude & West length \\
\hline $\mathrm{m} 1$ & \multirow{4}{*}{ Aridisol } & $10^{\circ} 17^{\prime} 32.7^{\prime \prime}$ & $76^{\circ} 9^{\prime} 32.6^{\prime \prime}$ \\
\hline $\mathrm{m} 2$ & & $10^{\circ} 16^{\prime} 57.7^{\prime \prime}$ & $76^{\circ} 9^{\prime} 38.7^{\prime \prime}$ \\
\hline $\mathrm{m} 3$ & & $10^{\circ} 17^{\prime} 18.1 "$ & $76^{\circ} 9^{\prime} 32.9^{\prime \prime}$ \\
\hline $\mathrm{m} 4$ & & $10^{\circ} 17^{\prime} 49.6^{\prime \prime}$ & $76^{\circ} 9^{\prime} 54.1 ”$ \\
\hline $\mathrm{m5}$ & \multirow{13}{*}{ Entisol } & $10^{\circ} 18^{\prime} 5.6^{\prime \prime}$ & $76^{\circ} 9^{\prime} 42.4^{\prime \prime}$ \\
\hline m6 & & $10^{\circ} 14^{\prime} 51.9^{\prime \prime}$ & $76^{\circ} 7^{\prime} 34.9^{\prime \prime}$ \\
\hline $\mathrm{m} 7$ & & $10^{\circ} 21^{\prime} 44.3^{\prime \prime}$ & $76^{\circ} 11^{\prime} 58.8^{\prime \prime}$ \\
\hline $\mathrm{m} 8$ & & $10^{\circ} 20^{\prime} 10.3{ }^{\prime \prime}$ & $76^{\circ} 11^{\prime} 9.8^{\prime}$ \\
\hline $\mathrm{m} 9$ & & $10^{\circ} 14^{\prime} 8.7^{\prime \prime}$ & $76^{\circ} 10^{\prime} 3.7^{\prime \prime}$ \\
\hline $\mathrm{m} 10$ & & $10^{\circ} 14^{\prime} 4.7^{\prime \prime}$ & $76^{\circ} 10^{\prime} 15.7^{\prime \prime}$ \\
\hline $\mathrm{m} 11$ & & $10^{\circ} 14^{\prime} 12.8^{\prime \prime}$ & $76^{\circ} 11^{\prime} 30.4^{\prime \prime}$ \\
\hline $\mathrm{m} 12$ & & $10^{\circ} 14^{\prime} 20.3^{\prime \prime}$ & $76^{\circ} 5^{\prime} 50.2^{\prime \prime}$ \\
\hline $\mathrm{m} 13$ & & $10^{\circ} 20^{\prime} 50.7^{\prime \prime}$ & $76^{\circ} 13^{\prime} 21.9^{\prime \prime}$ \\
\hline $\mathrm{m} 14$ & & $10^{\circ} 19^{\prime} 23.8^{\prime \prime}$ & $76^{\circ} 11^{\prime} 56.5^{\prime \prime}$ \\
\hline $\mathrm{m} 15$ & & $10^{\circ} 14^{\prime} 47.1 "$ & $76^{\circ} 7^{\prime} 52.3^{\prime \prime}$ \\
\hline $\mathrm{m} 16$ & & $10^{\circ} 16^{\prime} 3.0^{\prime \prime}$ & $76^{\circ} 7^{\prime} 40.6^{\prime \prime}$ \\
\hline $\mathrm{m} 17$ & & $10^{\circ} 18^{\prime} 11.9 \prime$ & $76^{\circ} 6^{\prime} 49.9^{\prime \prime}$ \\
\hline $\mathrm{m} 18$ & \multirow{6}{*}{ Histosol } & $10^{\circ} 14^{\prime} 26.9^{\prime \prime}$ & $76^{\circ} 5^{\prime} 31.5^{\prime \prime}$ \\
\hline m19 & & $10^{\circ} 14^{\prime} 34.9^{\prime \prime}$ & $76^{\circ} 5^{\prime} 20.0 ”$ \\
\hline $\mathrm{m} 20$ & & $10^{\circ} 18^{\prime} 44.6^{\prime \prime}$ & $76^{\circ} 14^{\prime} 33.4^{\prime \prime}$ \\
\hline $\mathrm{m} 21$ & & $10^{\circ} 19^{\prime} 49.5^{\prime \prime}$ & $76^{\circ} 3^{\prime} 2.7^{\prime \prime}$ \\
\hline $\mathrm{m} 22$ & & $10^{\circ} 19^{\prime} 50.3^{\prime \prime}$ & $76^{\circ} 2 ’ 30.9^{\prime \prime}$ \\
\hline $\mathrm{m} 23$ & & $10^{\circ} 20^{\prime} 1.1 "$ & $76^{\circ} 4^{\prime} 38.6^{\prime \prime}$ \\
\hline $\mathrm{m} 24$ & \multirow{13}{*}{ Inceptisol } & $10^{\circ} 15^{\prime} 14.8^{\prime \prime}$ & 769'19.9"' \\
\hline $\mathrm{m} 25$ & & $10^{\circ} 18^{\prime} 26.4^{\prime \prime}$ & $76^{\circ} 9^{\prime} 52.8^{\prime \prime}$ \\
\hline $\mathrm{m} 26$ & & $10^{\circ} 13^{\prime} 33.0^{\prime \prime}$ & $76^{\circ} 6^{\prime} 37.8^{\prime \prime}$ \\
\hline $\mathrm{m} 27$ & & $10^{\circ} 19^{\prime} 1.1 ”$ & $76^{\circ} 11^{\prime} 21.3^{\prime \prime}$ \\
\hline $\mathrm{m} 28$ & & $10^{\circ} 15^{\prime} 25.4^{\prime \prime}$ & 767'39.9”' \\
\hline $\mathrm{m} 29$ & & $10^{\circ} 14^{\prime} 19.8^{\prime \prime}$ & $76^{\circ} 6^{\prime} 18.4^{\prime \prime}$ \\
\hline m30 & & $10^{\circ} 14^{\prime} 36.7^{\prime \prime}$ & $76^{\circ} 6^{\prime} 46.8^{\prime \prime}$ \\
\hline $\mathrm{m} 31$ & & $10^{\circ} 18^{\prime} 10.4^{\prime \prime}$ & $76^{\circ} 6^{\prime} 53.1 ”$ \\
\hline $\mathrm{m} 32$ & & $10^{\circ} 21^{\prime} 32.9^{\prime \prime}$ & $76^{\circ} 13^{\prime} 7.7^{\prime \prime}$ \\
\hline m33 & & $10^{\circ} 20^{\prime} 24.1 "$ & $76^{\circ} 7^{\prime} 22.6^{\prime \prime}$ \\
\hline m34 & & $10^{\circ} 21^{\prime} 36.4^{\prime \prime}$ & $76^{\circ} 6^{\prime} 56.9^{\prime \prime}$ \\
\hline m35 & & $10^{\circ} 23^{\prime} 0.5^{\prime \prime}$ & $76^{\circ} 4^{\prime} 50.1 "$ \\
\hline $\mathrm{m} 36$ & & $10^{\circ} 23^{\prime} 15.7^{\prime \prime}$ & $76^{\circ} 6^{\prime} 48.3^{\prime \prime}$ \\
\hline $\mathrm{m} 37$ & \multirow{6}{*}{ Mollisol } & $10^{\circ} 20^{\prime} 49.6^{\prime \prime}$ & $76^{\circ} 13^{\prime} 57.8^{\prime \prime}$ \\
\hline $\mathrm{m} 38$ & & $10^{\circ} 20^{\prime} 59.3^{\prime \prime}$ & $76^{\circ} 14^{\prime} 43.3^{\prime \prime}$ \\
\hline m39 & & $10^{\circ} 19^{\prime} 47.3^{\prime \prime}$ & $76^{\circ} 15^{\prime} 11.4^{\prime \prime}$ \\
\hline $\mathrm{m} 40$ & & $10^{\circ} 19^{\prime} 21.7^{\prime \prime}$ & $76^{\circ} 14^{\prime} 48.8^{\prime \prime}$ \\
\hline $\mathrm{m} 41$ & & $10^{\circ} 19^{\prime} 31.4{ }^{\prime \prime}$ & $76^{\circ} 14^{\prime} 42.0^{\prime \prime}$ \\
\hline $\mathrm{m} 42$ & & $10^{\circ} 19^{\prime} 45.7^{\prime \prime}$ & $76^{\circ} 14^{\prime} 40.2^{\prime \prime}$ \\
\hline
\end{tabular}

\section{Materials and Methods}

\section{Description of the study area}

The study was conducted in the San Rafael district of Ambo province, located in the Huanuco Department, Peru. This place covers an area of 44,189.73 ha., located between the coordinates: lower-right end is $10^{\prime} 27^{\prime} 41.83^{\prime \prime} \mathrm{S}$ and $76^{\prime} 1^{\prime} 32.14^{\prime \prime} \mathrm{O}$; and the topleft end is 10'12'17.43" $\mathrm{S}$ and $76^{\prime} 15^{\prime} 16.33^{\prime \prime} \mathrm{O}$ (Figure 1). The 42 samples were analyzed in the Soil Laboratory of the School of Geosciences of the Faculty of Sciences of the Universidad Nacional de Colombia, Medellin. 


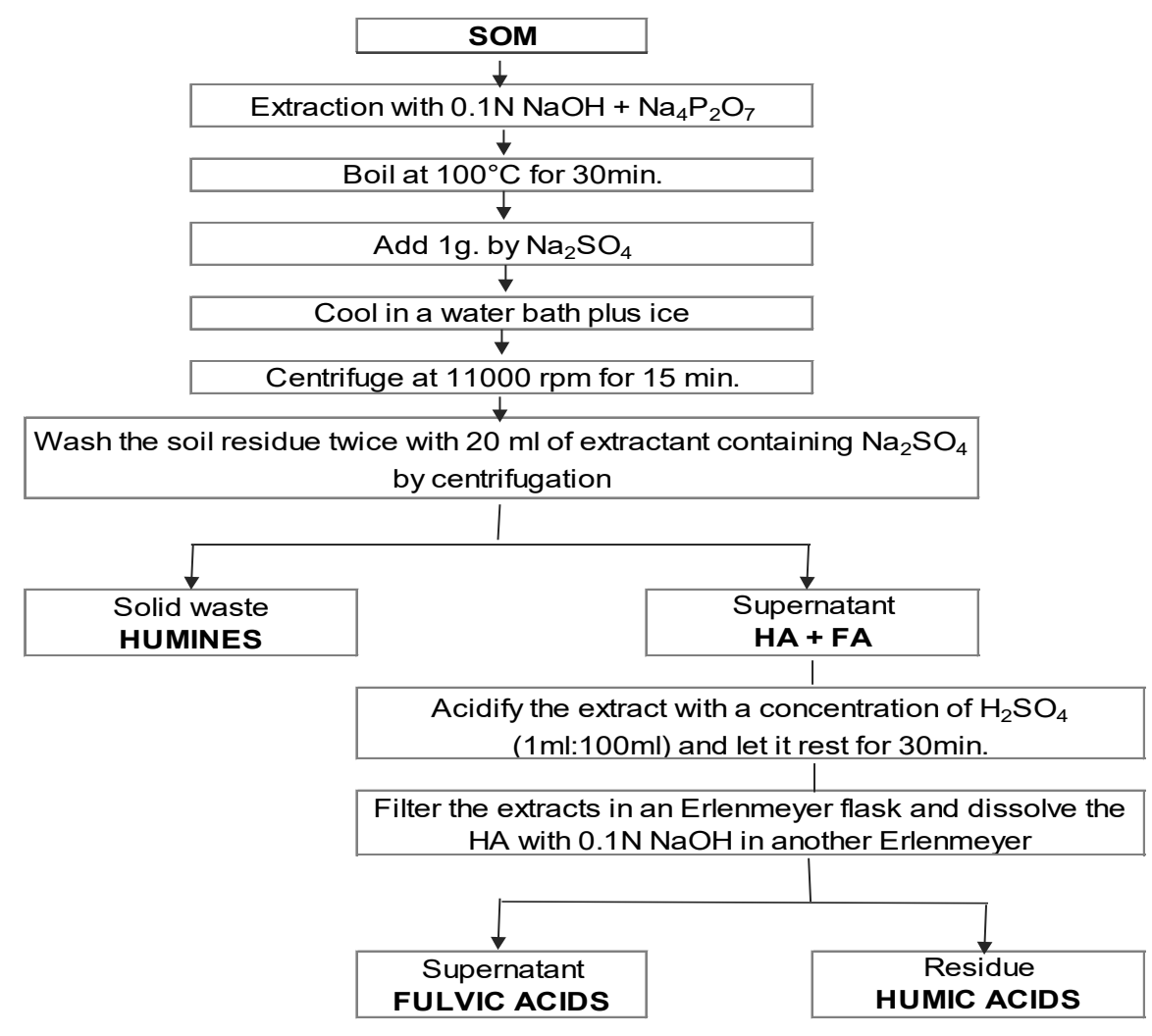

Figure 2: Extraction and fractionation of soil organic matter (Kumada, 1987).

\section{Sampling}

Forty-two simple samples were collected in the different soil orders (Soil Survey Staff, 2014) (Table 1). Sampling points were randomly distributed based on previous soil organic matter results. The samples were taken from the Epipedon, their morphological characteristics were described and those of the surrounding relief in field, also, have been georeferenced with GPS, coordinate reference system and datum WGS 84.

\section{Extraction and fractionation of organic matter from the soil}

The extraction and fractionation of organic matter from soil were carried out by the Nagoya method, described by Kumada (1987) according to Figure 2.

\section{Chemical characterization of humic acids}

The characterization of humic acids was performed according to Kumada (1987). This system group HAs into four types: A, B, P, and Rp, according to their position in the orthogonal axis diagram whose coordinates correspond to the RF and $\Delta \log$ $\mathrm{K}$ parameters. These parameters are obtained by the following expression:

$$
\begin{gathered}
\Delta \log K=\log K_{400}-\log K_{600} \\
R F=K_{600} \times 1,000 / c
\end{gathered}
$$

Where:

$\log K_{400}$ and $\log K_{600}$ is the optical density of an HA solution at $400 \mathrm{~nm}$ and $600 \mathrm{~nm}$., both spectrum ranges are obtained with a GENESYS Visible Spectrophotometer ${ }^{\mathrm{TM}} 20$.

$\mathrm{c}=$ volume in $\mathrm{ml}$ of $0.1 \mathrm{~N}$ of $\mathrm{KMnO}_{4}$ consumed by $30 \mathrm{~mL}$ of HA solution used to determine the absorption spectrum. In this investigation, $\mathrm{KMnO}_{4}$ was replaced by $0.1 \mathrm{~N}$ of $\mathrm{K}_{2} \mathrm{Cr}_{2} \mathrm{O}_{7}$.

\section{Quantification of organic carbon}

The organic carbon (OC) content in humic and fulvic acids was determined using the wet combustion method by Walkley and Black (1934). The organic forms of soil $\mathrm{C}$ oxidize in the presence of excess dichromate in the middle of a strong acid. After the oxidation stage of $\mathrm{C}$, at the reaction temperature for a certain period, the non-reduced $\mathrm{Cr}^{+6}$ added in excess was valued with ferrous sulfate $\mathrm{Fe}^{+2}$. The difference between these two states of $\mathrm{Cr}$ oxidation is equal to the organic carbon content of the sample (Allison et al., 1965; Walkley, 1947). 


\section{Obtaining morphoclimatic factors}

The morphometric parameters of the relief were obtained from the Digital Elevation Model (DEM) of the RADARSAT-2 satellite in masl. The spatial resolution of 6 meters of the DEM was resampled to 30 meters, and the following morphometric parameters were obtained: terrain slope, slope orientation (aspect), the curvature of the slope (profile and flat curvature), and Topographic Wetness Indexes (TWI). This extraction of morphometric parameters was performed using Geographic Information System (GIS) techniques using GRASS GIS version 7.4.1 software.

The next factor of the state is the climate. The most important variables are humidity (h) and temperature $(\mathrm{t})$. This research worked with a single climate component, which is the annual temperature of the Earth's surface.

The temperature subfactor was obtained from the MODIS sensor in degrees Celsius. This MODIS product (MOD11A2, version 6) provides a Land Surface Temperature (LST) every 8 days of day and night data per pixel at a spatial resolution of $1 \mathrm{~km}$ (Wan et al., 2015). The data were obtained from EARTHDATA (National Aeronautics and Space Administration-NASA) from 2008 to 2018, and the annual temperature calculation was subsequently performed.

\section{Statistical analysis}

The relationships between the morphoclimatic parameters and the degree of humification were performed by ordinal logistic regression analysis. Simple linear regression and multiple linear regression were used to understand the relationship of morphoclimatic parameters to the contents of HA and FA. These tests used a significance level of $(\mathrm{p}<0.05)$.

For the relief factor, the quantitative relationships of organic carbon from humic acids (HA), fulvic acids (FA), and the degree of humification require compliance with the following equation:

$$
O C=f(\text { relief) } c l, o, p, t \ldots
$$

All factors, except relief, must be kept constant.

For the climate factor, the quantitative relationships of organic carbon in HA, in FA, and degree of humification, the following equation is required to be met:

$$
O C=f(\text { temperature }) o, r, p, t \ldots
$$

All factors, except temperature, must be kept constant.

\section{Results and Discussion}

\section{Degree of humification and state factor that conditions the humification process}

The degree of humification in mountain soils show the predominance of humic acid types in the following order: $\mathrm{P}>\mathrm{B}>\mathrm{A}>\mathrm{Rp}$ (see Table 2 and Figure 3). This codification of Kumada (1987) proposes the theory for the formation of HA. The start of the humification process begins with the $\mathrm{Rp}$ type (first humification states of organic matter), evolving to type B, and finally, type A (each type exhibits a relatively stable form). In strongly acidic soils, type $\mathrm{P}$ replaces the Rp type. The mountain soils of the order Histosol are classified as Type Rp (2) and Type P (first humification states), the order Inceptisol as Type P, B, and A (immature to mature state), the order Mollisol as Type P and A (immature and mature state) and the soils of the order Aridisol and Entisol as Type P and B (immature state and evolved to the mature form).

In establishing the relationship of morphoclimatic factors with the degree of humification, the relief factor was identified as the condition for the humification process to occur. An ordinal logistic regression analysis, only the slope profile curvature parameter or subfactor presents a significant relationship $(p<0.05)$, while the slope subfactors, slope orientation (aspect), flat curvature, topographical index of humidity, and the Land Surface Temperature did not present a significant relationship.

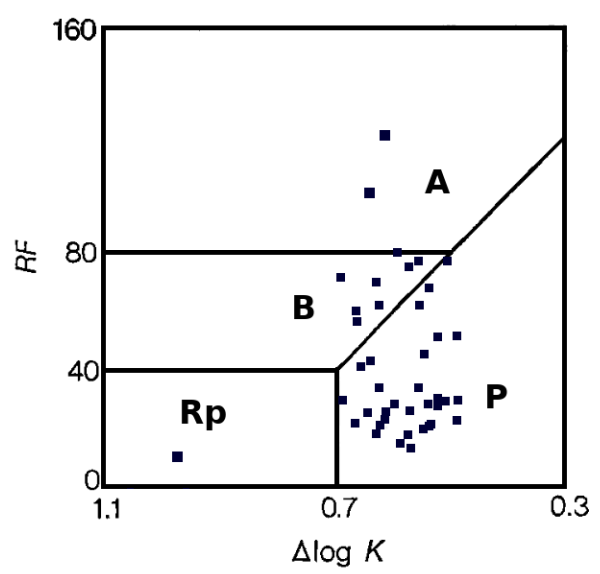

Figure 3. Classification of types of humic acids in mountain soils. 
Table 2: Organic carbon content from humic and fulvic acids, and the degree of humification in different soil orders.

\begin{tabular}{|c|c|c|c|c|c|c|}
\hline $\begin{array}{c}\text { Soil } \\
\text { sample }\end{array}$ & $\begin{array}{c}\text { Soil order (Soil Survey } \\
\text { Staff) }\end{array}$ & $\begin{array}{c}\begin{array}{c}\text { Organic carbon in } \\
\text { HA }\end{array} \\
\left(\mathrm{g} 100 \mathrm{~g}^{-1}\right)\end{array}$ & $\begin{array}{c}\text { Organic carbon in } \\
\text { FA } \\
\left(\text { g } 100 \mathrm{~g}^{-1}\right)\end{array}$ & RF & $\Delta \log K$ & $\begin{array}{c}\text { Type of } \\
\text { HA }\end{array}$ \\
\hline $\mathrm{m} 1$ & \multirow{4}{*}{ Aridisol } & 0.05 & 0.05 & 75 & 0.57 & B \\
\hline $\mathrm{m} 2$ & & 0.15 & 0.10 & 23 & 0.67 & $\mathrm{P}$ \\
\hline $\mathrm{m} 3$ & & 0.15 & 0.05 & 57 & 0.68 & B \\
\hline $\mathrm{m} 4$ & & 0.15 & 0.20 & 34 & 0.56 & $\mathrm{P}$ \\
\hline $\mathrm{m} 5$ & \multirow{13}{*}{ Entisol } & 0.15 & 0.15 & 42 & 0.64 & $\mathrm{P}$ \\
\hline $\mathrm{m} 6$ & & 0.20 & 0.35 & 60 & 0.67 & B \\
\hline $\mathrm{m} 7$ & & 0.10 & 0.05 & 45 & 0.55 & $\mathrm{P}$ \\
\hline $\mathrm{m} 8$ & & 0.15 & 0.05 & 26 & 0.65 & $\mathrm{P}$ \\
\hline $\mathrm{m} 9$ & & 0.15 & 0.10 & 41 & 0.66 & $\mathrm{P}$ \\
\hline $\mathrm{m} 10$ & & 0.05 & 0.05 & 62 & 0.55 & $\mathrm{P}$ \\
\hline $\mathrm{m} 11$ & & 0.10 & 0.05 & 70 & 0.63 & B \\
\hline $\mathrm{m} 12$ & & 1.00 & 1.50 & 53 & 0.45 & $\mathrm{P}$ \\
\hline $\mathrm{m} 13$ & & 0.15 & 0.05 & 28 & 0.70 & $\mathrm{P}$ \\
\hline $\mathrm{m} 14$ & & 0.15 & 0.10 & 66 & 0.54 & $\mathrm{P}$ \\
\hline $\mathrm{m} 15$ & & 0.75 & 0.10 & 18 & 0.55 & $\mathrm{P}$ \\
\hline $\mathrm{m} 16$ & & 0.15 & 0.10 & 61 & 0.62 & B \\
\hline $\mathrm{m} 17$ & & 0.45 & 0.20 & 24 & 0.61 & $\mathrm{P}$ \\
\hline $\mathrm{m} 18$ & \multirow{6}{*}{ Histosol } & 6.00 & 1.75 & 29 & 0.55 & $\mathrm{P}$ \\
\hline $\mathrm{m} 19$ & & 3.75 & 1.25 & 20 & 0.54 & $\mathrm{P}$ \\
\hline $\mathrm{m} 20$ & & 2.10 & 0.30 & 26 & 0.57 & $\mathrm{P}$ \\
\hline $\mathrm{m} 21$ & & 11.00 & 3.50 & 10 & 0.96 & $\mathrm{Rp}(2)$ \\
\hline $\mathrm{m} 22$ & & 5.25 & 1.00 & 29 & 0.51 & $\mathrm{P}$ \\
\hline $\mathrm{m} 23$ & & 5.25 & 0.75 & 23 & 0.50 & $\mathrm{P}$ \\
\hline $\mathrm{m} 24$ & \multirow{13}{*}{ Inceptisol } & 0.20 & 0.20 & 35 & 0.63 & $\mathrm{P}$ \\
\hline $\mathrm{m} 25$ & & 0.15 & 0.30 & 73 & 0.69 & $\mathrm{P}$ \\
\hline $\mathrm{m} 26$ & & 1.20 & 0.10 & 15 & 0.58 & $\mathrm{P}$ \\
\hline $\mathrm{m} 27$ & & 0.05 & 0.05 & 17 & 0.63 & $\mathrm{P}$ \\
\hline $\mathrm{m} 28$ & & 0.90 & 0.25 & 17 & 0.57 & $\mathrm{P}$ \\
\hline $\mathrm{m} 29$ & & 0.25 & 0.30 & 80 & 0.58 & B \\
\hline $\mathrm{m} 30$ & & 2.10 & 0.50 & 26 & 0.59 & $\mathrm{P}$ \\
\hline $\mathrm{m} 31$ & & 0.15 & 0.20 & 123 & 0.62 & A \\
\hline $\mathrm{m} 32$ & & 0.15 & 0.05 & 77 & 0.56 & B \\
\hline m33 & & 0.60 & 0.05 & 20 & 0.62 & $\mathrm{P}$ \\
\hline m34 & & 0.90 & 0.40 & 29 & 0.53 & $\mathrm{P}$ \\
\hline $\mathrm{m} 35$ & & 1.00 & 1.00 & 76 & 0.52 & $\mathrm{P}$ \\
\hline $\mathrm{m} 36$ & & 4.50 & 1.00 & 23 & 0.62 & $\mathrm{P}$ \\
\hline m37 & \multirow{6}{*}{ Mollisol } & 0.15 & 0.35 & 104 & 0.64 & $\bar{A}$ \\
\hline $\mathrm{m} 38$ & & 2.50 & 0.75 & 27 & 0.53 & $\mathrm{P}$ \\
\hline m39 & & 4.50 & 0.50 & 13 & 0.57 & $\mathrm{P}$ \\
\hline $\mathrm{m} 40$ & & 1.50 & 0.50 & 51 & 0.50 & $\mathrm{P}$ \\
\hline $\mathrm{m} 41$ & & 3.00 & 0.75 & 20 & 0.54 & $\mathrm{P}$ \\
\hline $\mathrm{m} 42$ & & 5.25 & 1.50 & 29 & 0.50 & $\mathrm{P}$ \\
\hline
\end{tabular}

Profile curvature measures the rate of change of the slope with changes in the distance; this parameter relates to the flow velocity and the processes of transporting particles on the slope. On the slopes of the mountains, it is common to find sigmoidal profiles, i.e. profiles consisting of a convex upper segment, a straight intermediate segment, and a concave lower segment (Derruau, 1966; Ruhe, 1975).

Figure 4 shows the profile curvature segments that condition the degree of humification. In the convex segment, divergent flow and erosion are the 
Table 3: Coefficients between the morphoclimatic variables and the degree of humification ( $\mathrm{p}$ is the level of significance).

\begin{tabular}{|c|c|c|}
\hline \multicolumn{3}{|c|}{ Ordinal logistic regression (relief factor) } \\
\hline & \multicolumn{2}{|c|}{ Degree of humification of $\mathrm{HA}$} \\
\hline & Coefficients & p-value \\
\hline Slope of the terrain & 0.010 & $0.71 \mathrm{~ns}$ \\
\hline Slope orientation (aspect) & 0.002 & $0.45 \mathrm{~ns}$ \\
\hline Profile curvature & 0.060 & $* 0.04$ \\
\hline Flat curvature & -0.003 & $0.82 \mathrm{~ns}$ \\
\hline Topographical moisture index & 0.542 & $0.09 \mathrm{~ns}$ \\
\hline \multicolumn{3}{|c|}{ Ordinal logistic regression (climate factor) } \\
\hline & \multicolumn{2}{|c|}{ Degree of humification of $\mathrm{HA}$} \\
\hline & Coefficient & p-value \\
\hline Land surface temperature & -0.348 & $0.08 \mathrm{~ns}$ \\
\hline
\end{tabular}

Note: ns: Not Significant. ${ }^{*} \mathrm{p}<0.05$

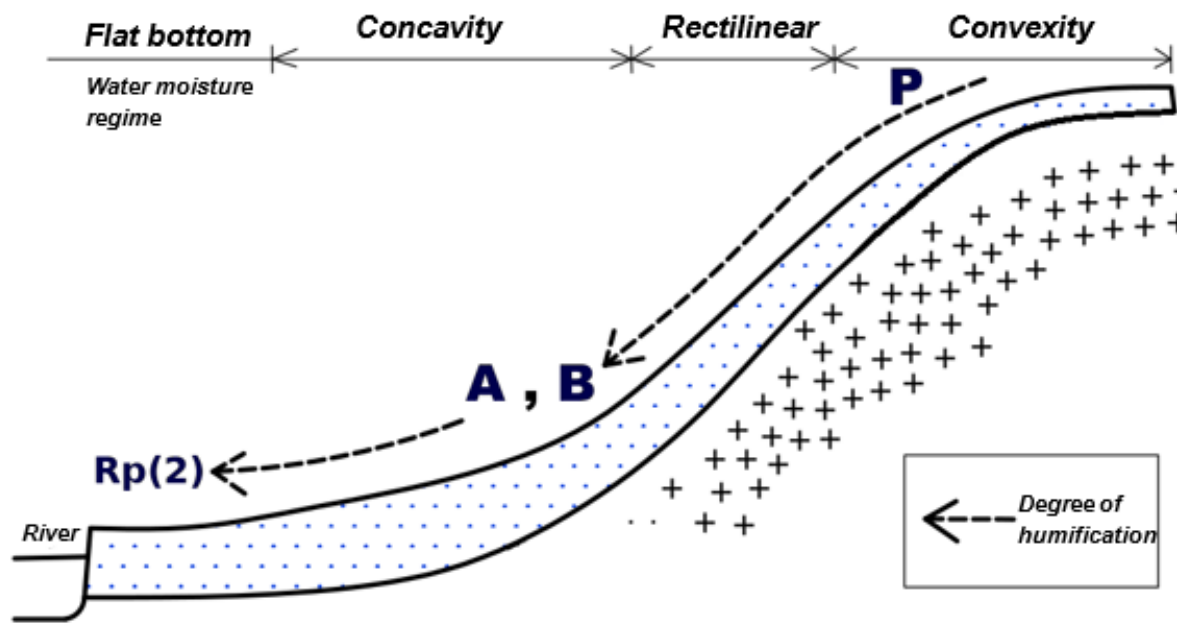

Figure 4: Degree of humification in the profile curvature of the slope.

dominant processes (Hall, 1983; Schaetzl, 2013). In this segment, the most likely degree of humification is Type $\mathrm{P}$ (immature state), due to the low persistence of water in materials, faster flow, and more intense erosion. These conditions are not conducive to the development and stability of the humus.

The straight segment occupies the middle part of the slope and is characterized by a very homogeneous inclination in its route. The dominant process in this location is a transit condition, for water and materials, without significant accumulations or removals of materials (Schaetzl, 2013). In this position, the degree of humification varies from Type $\mathrm{P}, \mathrm{B}$, and A (immature to mature state). This variability also occurs in the development of soil diagnostic horizons (Hall, 1983). Type $\mathrm{P}$ is in the transition to the convex segment, while Types A and B are likely to be in the concavity.
The concave segment, located at the lower part of the slope, acts as a recipient of sediment deposition and concentration of runoff waters, subsurface flow, and part of the water table. Likewise, the persistence of moisture in the materials underlying this segment is greater than in the segments of the middle and upper part (Hall, 1983; Schaetzl, 2013). The degree of humification is typed A and B (corresponds to the most evolved grade, but each type exhibits a relatively stable form). In this position of the slope, organic matter increases by favorable water retention conditions (Hall, 1983).

Finally, the flat bottoms, located above 3900 masl have an acidic moisture regime. In this sector, the degree of humification is of type Rp and corresponds to the beginning of the humification process in one of the soils of the order Histosol. These soils develop under conditions of restricted drainage and near- 
continuous water saturation over time. The difficulty of oxygen circulation in these conditions prevents the breakdown of plant remains and thus allows their accumulation as plant materials in different states of decomposition (Stevenson, 1994; Buol et al., 2011).

State factor that conditions the organic carbon content in humic acids (HA) and fulvic acids (FA)

In Table 4, it can be observed that the variable Land Surface Temperature (climate factor) acts as an important factor that expresses effectiveness in the organic carbon content in the fraction of HA and FA since the coefficient presents a steep slope. The Topographic Moisture Index, a morphoclimatic index, exerts low effectiveness in the organic carbon content of humic acids.
Figure 5 shows the inverse relationship between the Land Surface Temperature and the OC content in humic acids and fulvic acids, i.e. an increase in temperature decreases the $\mathrm{CO}$ content in $\mathrm{HA}$ and FA in different soils. Jenny et al., (1948) also found an inverse relationship between organic matter and temperature in Colombia. In some soils in Venezuela, the organic carbon content was found to increase with altitude and was associated with a decrease in temperature, mainly for regions located above 3000 masl (Ochoa et al., 1981).

$\mathrm{OC}$ in $\mathrm{HA}$ and FA fractions decrease to temperate areas greater than $22{ }^{\circ} \mathrm{C}$ (Figure 4). These very high-temperature conditions have a significant influence on maximum mineralization well above

Table 4: Coefficients between morphoclimatic variables and organic carbon content in HA and FA (p is significance level).

\begin{tabular}{|c|c|c|c|c|}
\hline \multicolumn{5}{|c|}{ Multiple linear regression (relief factor) } \\
\hline & \multicolumn{2}{|c|}{ CO in the HA } & \multicolumn{2}{|c|}{ CO in the FA } \\
\hline & Coefficients & p - value & Coefficients & p - value \\
\hline Intercept & -0.870 & & -0.174 & \\
\hline Slope of the terrain & -0.025 & $0.24 \mathrm{~ns}$ & -0.005 & $0.39 \mathrm{~ns}$ \\
\hline Slope orientation (aspect) & 0.002 & $0.33 \mathrm{~ns}$ & 0 & $0.41 \mathrm{~ns}$ \\
\hline Profile curvature & 0.026 & $0.32 \mathrm{~ns}$ & 0 & $0.97 \mathrm{~ns}$ \\
\hline Flat curvature & 0.010 & $0.54 \mathrm{~ns}$ & 0.001 & $0.69 \mathrm{~ns}$ \\
\hline Topographical moisture index & 0.443 & $0.06 \mathrm{~ns}$ & 0.109 & $0.11 \mathrm{~ns}$ \\
\hline \multicolumn{5}{|c|}{ Simple linear regression (climate factor) } \\
\hline & \multicolumn{2}{|c|}{ HA organic carbon } & \multicolumn{2}{|c|}{ FA organic carbon } \\
\hline & Coefficients & p - value & Coefficients & p - value \\
\hline Intercept & 18.513 & & 5.09 & \\
\hline Land surface temperature & -0.774 & $* 1.18 \times 10^{-7}$ & -0.21 & $* 5.64 \times 10^{-7}$ \\
\hline
\end{tabular}

Note: ns: Not Significant. ${ }^{*} \mathrm{p}<0.05$
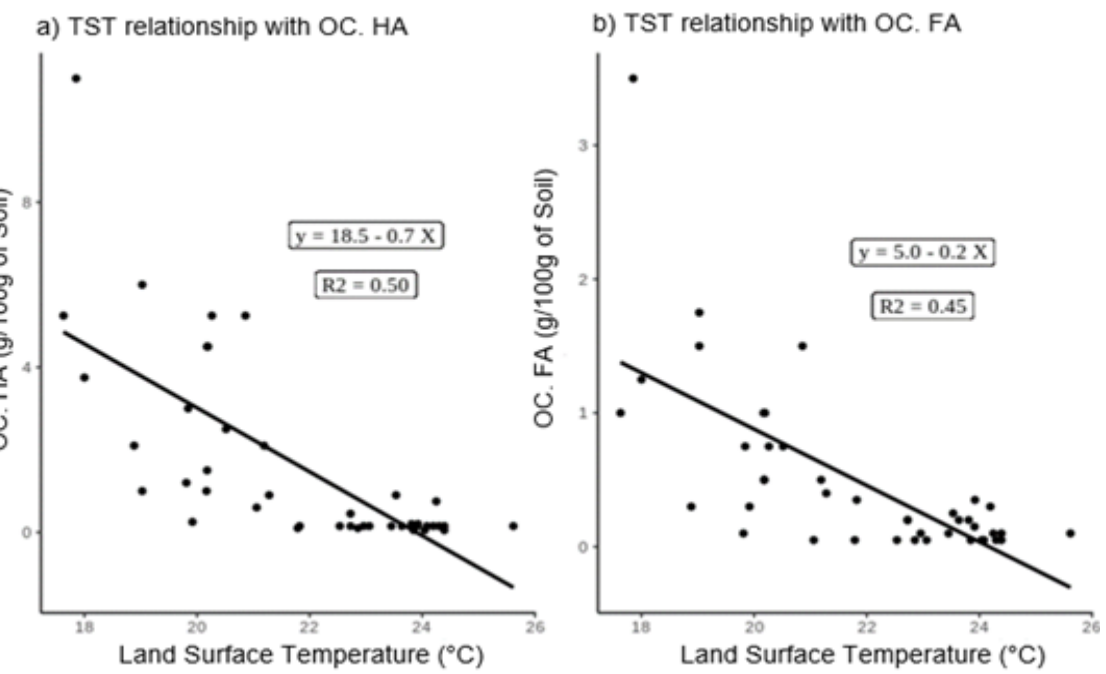

Figure 5: Relationship between Land Surface Temperature (LST) and organic carbon contents. a) LST with OC in humic acids and b) TST with OC fulvic acids. 
humification (Bartholomew \& Clark, 1965). Therefore, at temperatures below $22{ }^{\circ} \mathrm{C}$ organic matter accumulation and increased wetting rate occur.

\section{Conclusion}

The research carried out states that the degree of humification is conditioned by the relief factor and the organic carbon content in HA and FA is conditioned by the climate factor. The morphoclimatic parameters that influence these relationships are the profile curvature of the slope and the temperature of the terrain surface according to multiple linear regression.

\section{References}

Allison, L. E., Bollen, W. B., \& Moodie, C. D. (1965). Total carbon. In A. G. Norman (Ed.), Methods of soil analysis. Part 2. Chemical and microbiological properties (pp. 1346-1366).

Bartholomew, W. V., \& Clark, F. E. (1965). Soil nitrogen (No. 631.41 S683s). American Society of Agronomy, Madison, WI (EUA)

Buol, S. W., Southard, R. J., Graham, R. C., \& McDaniel, P. A. (2011). Soil Genesis and Classification. Sixth Edition. John Wiley \& Sons, Chichester.

Christensen, B. T. (1992). Physical fractionation of soil and organic matter in primary particle size and density separates. In B. A. Stewart (Ed.), Advances in soil science (pp. 1-90). Springer, New York, NY.

Derruau, M. (1966). Geomorfología. Barcelona: Ediciones Ariel.

Gallardo J. F. (2016). La materia orgánica del suelo: Residuos orgánicos, humus, compostaje, captura de carbono. Editorial S.i.F. y Q.A., Salamanca (España).

Hall, G. F. (1983). Pedology and geomorphology. In L. P. Wilding, N. E. Smeck, G. F. Hall (Eds.), Developments in Soil Science (pp. 117-140). Elsevier.

Jenny, H. (1941). Factors of soil formation. A system of quantitative pedology. McGraw-Hill. New York.

Jenny, H. (1980). The Soil Resource, Origin, and Behavior. Springer, New York

Jenny, H., Bingham, F., \& Padilla-Saravia, B. (1948). Nitrogen and organic matter contents of equatorial soils of Colombia, South America. Soil Science, 66(3), 173-186.

Kononova, M. M. (1975). Humus of virgin and cultivated soils. In J. E. Gieseking (Ed.), Soil components (pp. 475-526). Springer, Berlin, Heidelberg.

Kumada, K. (1987). Chemistry of soil organic matter. Japan Scientific Societies Press. Elsevier. Tokyo.
Ochoa, G. R., Malagón C. D., \& Pereyra J. (1981). El contenido de materia orgánica, nitrogeno total y factores que los afectan en algunos suelos de Venezuela. CIDIAT, SC-44.

Osorio, N. W. (2018). Manejo de nutrientes en suelos del trópico. Medellín: Universidad Nacional de Colombia.

Ruhe, R. V. (1975). Geomorphology: geomorphic processes and surficial geology. Houghton Mifflin, Boston.

Schaetzl, R. J. (2013). Catenas and soils. In J. Shroder, G. A. Pope (Eds.), Treatise on Geomorphology (pp. 145-158). Academic Press, San Diego.

Soil Survey Staff (2014). Keys to Soil Taxonomy, 12th ed. USDANatural Resources Conservation Service, Washington, DC.

Stevenson, F. J. (1994). Humus chemistry: genesis, composition, reactions. John Wiley \& Sons. 2nd ed. John Wiley \& Sons, New York.

Walkley, A. \& Black, I. A. (1934). An examination of the Degtjareff method for determining soil organic matter, and a proposed modification of the chromic acid titration method. Soil science, 37(1), 29-38.

Walkley, A. (1947). A critical examination of a rapid method for determining organic carbon in soils-effect of variations in digestion conditions and of inorganic soil constituents. Soil science, 63(4), 251-264.

Wan, Z., Hook, S., \& Hulley, G. (2015). MOD11A2 MODIS/ Terra Land Surface Temperature/Emissivity 8-Day L3 Global $1 \mathrm{~km}$ SIN Grid V006 [Data set]. NASA EOSDIS LP DAAC. https://doi: 10.5067/MODIS/MOD11A2.006

Zaccone, C., Plaza, C., Ciavatta, C., Miano, T. M., \& Shotyk, W. (2018). Advances in the determination of humification degree in peat since: Applications in geochemical and paleoenvironmental studies. Earth-science reviews, 185, 163-178. 